\title{
NATURAL HISTORY NOTE First report of intraspecific variation in wing translucency for a Neotropical bat
species
}

\author{
Hernani F. M. Oliveira ${ }^{1,}{ }^{*}$, Sandra L. Peters ${ }^{2}$, Russell J. Gray ${ }^{3}$, Roberto Leonan M. Novaes ${ }^{4}$
}

${ }^{1}$ Universidade Federal do Paraná, Avenida Coronel Francisco Heráclito dos Santos 100, CEP 81531-980, Curitiba Brazil

${ }^{2}$ Independent Researcher, Toronto, Canada

${ }^{3}$ Independent Researcher, 705 Alligator Ranch Rd. New Smyrna Beach, Florida, United States of America. 32168

${ }^{4}$ Universidade Federal do Rio de Janeiro, Programa de Pós-Graduação em

Biodiversidade e Biologia Evolutiva. Av.

Carlos Chagas Filho 373, CEP 21941-902,

Rio de Janeiro, Brazil

*Corresponding author:

oliveiradebioh@gmail.com

DOI:https://doi.org/10.14709/

BarbJ.14.1.2021.05

Keywords: Chiroptera, Emballonuridae, Amazon forest, Brazil, patagium

received: November, 27th 2020

accepted: April, 22nd 2021

Intraspecific colour variation in bats is a widespread phenomenon that has been observed by many field researchers in the tropics. Bat wing membrane colour naturally ranges between species from black, yellow, orange or translucent (Vaughan \& Vaughan 1986, Patel et al. 2017, Rydell et al. 2020). Although most intraspecific differences in bat colour patterns have been reported for fur (Uieda 2000, Oliveira \& Aguiar 2008, Lucati \& López-Baucells 2017), there have also been a few reported cases of intraspecific variation in wing membrane colour (Koopman 1994, Garbutt 2007, Monadjem et al. 2010), but none for the Neotropical region. Although chromatic aberrations have been reported in many species, they are caused by either a deficiency in or an excess of pigment and the reasons behind them are multiple and rather underexplored.

Pale (i.e., clear or translucent) wings have been found in bats of a wide range of body sizes belonging to aerial insectivorous species that possess long and narrow wings adapted for straight, fast flight (Barclay 1985, Norberg \& Rayner 1987, Rydell et al. 2020). As Rydell et al. (2020) indicated, darker wings may provide increased camouflage against the dark sky and thereby influence foraging patterns and emergence times among bat species. Interspecific colour variation in wings may also be associated with thermoregulation as bat wings are highly vascularized (Kluger \& Heath 1970). Wing temperature tends to be significantly cooler than body temperatures, and dark colours can absorb a higher amount of solar radiation than other colours (Speakman \& Hays 1992, Speakman et al. 1994, Rummel et al. 2019). Another possibility may be that translucent wings allow bats to see their surroundings while at rest without the need to open their wings (Vaughan 1970), which would enhance their response to predation pressure while keeping the wings closed for better body thermoregulation.

The genus Diclidurus consists of four species ( $D$. albus, $D$. ingens, $D$. isabella, D. scutatus) that occur in the Neotropics (Simmons 2005, Mammal Diversity Database 2020). The lesser ghost bat (Diclidurus scutatus) is a rarely captured canopy specialist insectivorous bat that roosts under palm tree leaves (Novaes et al. 2017). Although the species is widely distributed across the Amazon and Atlantic rainforests of South America (Novaes et al. 2017), the paucity of records has made intraspecific morphological comparisons challenging.

Here we report the first known case of intraspecific variation in wing translucency observed in two D. scutatus individuals captured at two sites located approximately 2,000 $\mathrm{km}$ apart in the Brazilian Amazon forest. One individual with fully translucent wings (Fig. 1A) (non-identified sex, age, or reproductive stage) was captured in January 2007 in a riparian corridor located on the outskirts of Monte Dourado 

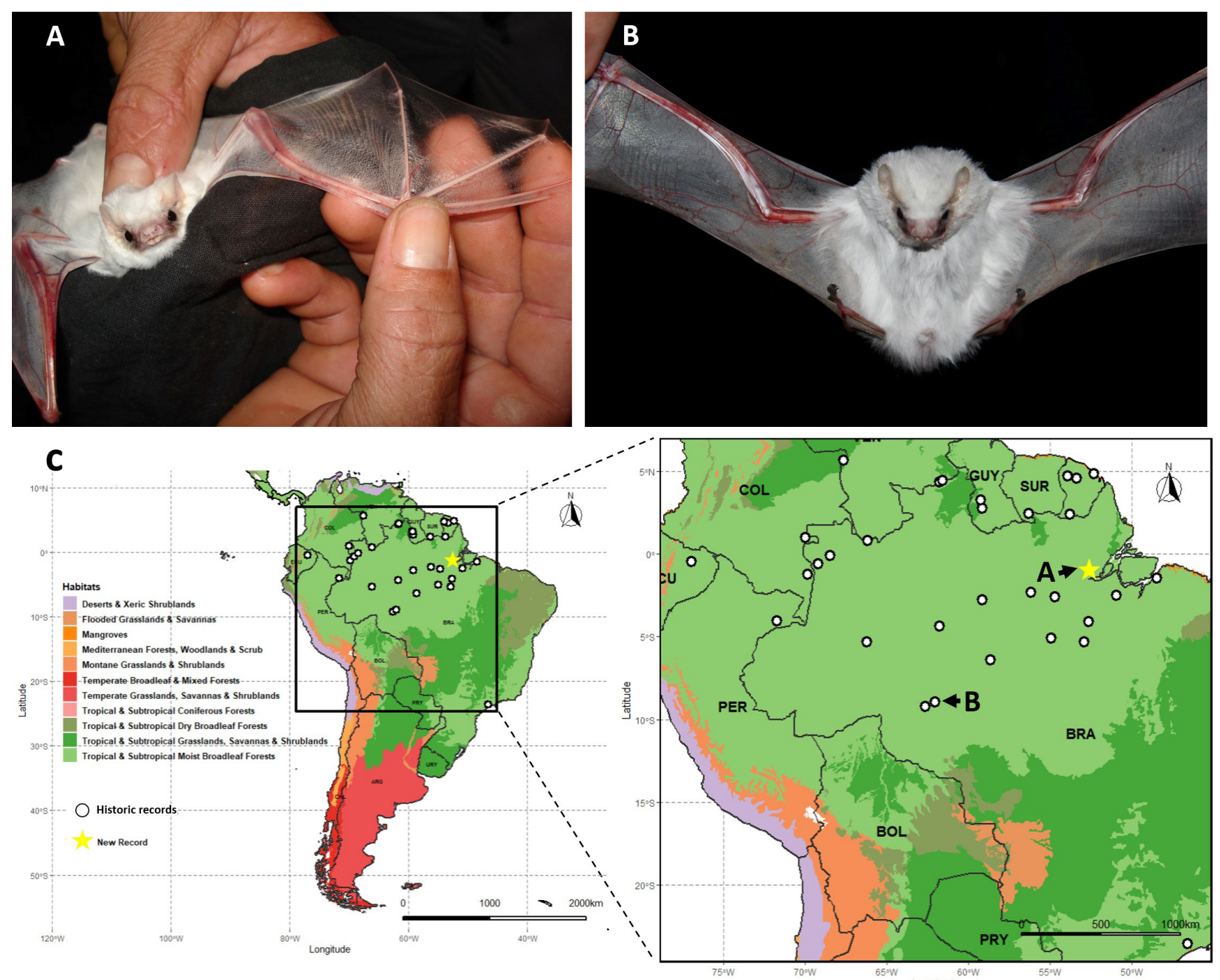

Fig. 1 - Images of the two lesser ghost bat (Diclidurus scutatus) individuals captured in 2007 (A) and 2014 (B), evidencing the intraspecific variation in wing translucency. (C) Map illustrating the localities where the two individuals were captured in the Brazilian Amazon forest (Site A: Almeirim, and Site B: Macadinho D'Oeste). The map was plotted using the package ggplot2 (Wickham et al. 2016) and the shapefile from Dinerstein et al. (2017) with the occurrences of D. scutatus recorded by Novaes et al. (2017) and available in the global biodiversity information facility (GBIF; www.gbif.org), including the new record from the present study.

(Almeirim, Pará, Brazil: 005'S 5236'W), in a canopy net set approximately 14 meters above the ground.

The second individual was a non-reproductive adult female captured in February 2014 with a mist net which was manually launched on bats that were foraging around a light pole in an open area nearby a village from the Vila Tabajara district (Machadinho D’Oeste, Rondônia, Brazil; 085'', $\left.62^{\circ} 03^{\prime} \mathrm{W}\right)$. In this case, the animal had whitish, opaque wings (Fig. 1B). The second individual has greatly extended the distribution of the species towards the Southern portion of the Amazon forest.

As an update to criteria metrics of the IUCN Redlist (IUCN 2020), we calculated the Extent of Occurrence (EOO) and Area of Occurrence (AOO) using the package 'conR' (Dauby et al. 2017) and the geographic coordinates of the occurrences of $D$. scutatus recorded by Novaes et al. (2017) and available in the global biodiversity information facility (GBIF; www.gbif.org), including the new record from the present study. To the best of our knowledge, this is the first reported case of intraspecific variation in wing translucency for a Neotropical emballonurid bat species and for any bat species in the Neotropical region.

Previous records of intraspecific variation in wing colour patterns have been recorded for Paleotropical bats, including emballonurids, and a vespertilionid, with wing colour ranging from brown to whitish (Mimetillus moloneyi and Taphozous perforatus), pale brown to light brown (Coleura afra), and translucent to olive brown (Saccolaimus saccolaimus) (Koopman 1994, Garbutt 2007, Francis 2008, Menkhorst \& Knight 2011). While we have observed translucent, almost fully transparent wings in the individual captured in the North-eastern Amazon, the individual captured in the Southern Brazilian Amazon had paler and more opaque wings. It is possible that the observed intraspecific translucency variation reported herein for D. scutatus is either a widespread phenomenon within Neotropical emballonurids and/or other bat families, or it could simply be restricted to few individuals.

The observed variation between the two captured $D$. scutatus individuals described herein may be explained by 
the following non-excluding hypotheses: (1) differences in light conditions among roost sites could select for different levels of wing translucency as a result of camouflage success (Endler 2006); (2) adaptations in pigmentation could be related to thermoregulation requirements in different environments, given that membranes contribute to significant heat loss in bats (Speakman \& Hays 1992); and (3) differences in forest and habitat structure between the two localities could affect habitat use due to different foraging successes for bat camouflage against the sky or canopy in each environment, with pale-winged individuals benefiting from foraging in more open spaces (Rydell et al. 2020).

The Amazon forest, where most of the large Extent of Occurrence of $D$. scutatus is localised (EOO= 5,731,327 $\mathrm{km}^{2}$ and $\mathrm{AOO}=132 \mathrm{~km}^{2}$ (Supplementary Material I)), has a complex biogeographic scenario where large rivers can impose important dispersal limits for flying animal species (Oliveira et al. 2017). Rivers can isolate populations of a species and cause geographic variation in a characteristic to be constrained to a specific geographic area. The presence of transparent wings for other emballonurid species (Lim \& Dunlop 2008) makes it important to evaluate the extent of variation for wing translucency among $D$. scutatus conspecifics. Thus, we suggest that museum specimens from different localities should be evaluated to thoroughly assess intraspecific morphological variation in wing colour among emballonurids to further investigate the differences that we describe herein.

\section{ACKNOWLEDGEMENTS}

We would like to thank the anonymous reviewers for the comments and Coordenação de Aperfeiçoamento de Pessoal de Nível Superior (http://www.capes.gov.br) for providing a scholarship to the first author (H. F. M. O.) during the period of this study.

\section{REFERENCES}

BARCLAY, R. M. R. (1985). Long- versus short-range foraging strategies of hoary (Lasiurus cinereus) and silver-haired (Lasionycteris noctivagans) bats and the consequences for prey selection. Can J Zool, 63(11): 2507-2515. https:// doi.org/10.1139/z85-371

DAUBY, G., STÉVART, T., DROISSART, V., COSIAUX, A., DEBLAUWE, V., SIMO-DROISSART, M., SOSEF, M. S. M., LOWRY II, P. P., SCHATZ, G. E., GEREAU, R. E., et al. (2017). ConR: An $R$ package to assist large-scale multispecies preliminary conservation assessments using distribution data. Ecol Evol, 7(24): 11292-11303. https://doi.org/10.1002/ ece3.3704

DINERSTEIN, E., OLSON, D., JOSHI, A., VYNNE, C., BURGESS, N. D., WIKRAMANAYAKE, E., HAHN, N., PALMINTERI, S., HEDAO, P., NOSS, R., et al. (2017). An ecoregion-based approach to protecting half the terrestrial realm. BioScience, 67(6): 534-545. https://doi.org/10.1093/biosci/ bix014
ENDLER, J. A. (2006). Disruptive and cryptic coloration. $P$ Roy Soc B-Biol Sci, 273(1600): 24252426. http://doi. org/10.1098/rspb.2006.3650

FRANCIS, C. M. (2008). A field guide to the mammals of South-East Asia. ed.: New Holland Publishers Ltd. London, United Kingdom, 392 pp.

GARBUTT, N. (2007). Mammals of Madagascar: a complete guide. ed.: Yale University Press. London, United Kingdom, 304 pp.

IUCN (2020). The IUCN Red List of Threatened Species. Version 2020-2. https://www.iucnredlist.org

KLUGER, M. J. \& HEATH, J. E. (1970). Vasomotion in the bat wing: A thermoregulatory response to internal heating. Comp Biochem Physiol, 32(2): 219-226. https://doi. org/10.1016/0010-406X(70)90935-7

KOOPMAN, K. F. (1994). Chiroptera: Systematics. In: Handbuch der Zoologie. Eine Naturgeschichte der Stämme des Tierreiches VIII, Mammalia, part 60. ed.: Walter de Gruyter Press. Berlin, Germany, p.1-127.

LIM, B. K. \& DUNLOP, J. M. (2008). Evolutionary patterns of morphology and behavior as inferred from a molecular phylogeny of new world emballonurid bats (Tribe Diclidurini). J Mamm Evol, 15: 79-121. https://doi. org/10.1007/s10914-007-9068-0

LUCATI, F. \& LÓPEZ-BAUCELLS, A. (2017). Chromatic disorders in bats: a review of pigmentation anomalies and the misuse of terms to describe them. Mammal Rev, 47(2): 112-123. https://doi.org/10.1111/mam.12083

MAMMAL DIVERSITY DATABASE. (2020). Mammal Diversity Database (Version 1.31). Zenodo. http://doi. org/10.5281/zenodo.4139818

MENKHORST, P. \& KNIGHT, F. (2011). A field guide to the mammals of Australia. Third edition. ed.: Oxford University Press. South Melbourne, Australia, 296 pp.

MONADJEM, A., TAYLOR, P. J., COTTERILL, F. P. D. \& SCHOEMAN, M. C. (2010). Bats of Southern and Central Africa: a biogeographic and taxonomic synthesis. ed.: Wits University Press. Johannesburg, South Africa, 596 pp.

NORBERG, U. M. \& RAYNER, J. M. V. (1987). Ecological morphology and flight in bats (Mammalia; Chiroptera): wing adaptations, flight performance, foraging strategy and echolocation. Philos T R Soc B, 316(1179): 335-427. https://doi.org/10.1098/rstb.1987.0030

NOVAES, R. L. M., CLÁUDIO, V. C. \& KUNIY, A. A. (2017). Range extension of Diclidurus scutatus (Chiroptera, Emballonuridae) to southwestern Amazonia. Acta Amazon, 47(4): 359-364. https://doi.org/10.1590/18094392201700083

OLIVEIRA, H. F. M. \& AGUIAR, L. M. S. (2008). A new case of complete albinism in a bat from Brazil. Chiroptera Neotropical, 14(2): 421-423. 
OLIVEIRA, U., VASCONCELOS, M. F. \& SANTOS, A. J. (2017). Biogeography of Amazon birds: rivers limit species composition, but not areas of endemism. Sci Rep-UK, 7: 2992. https://doi.org/10.1038/s41598-017-03098-w

PATEL, J., GAMIT, K., GAMIT, N. \& DEBATA, S. (2017). Painted bat, Kerivoula picta in Gujarat. Zoo's Print, 32(1): 13-16.

RUMMEL, A. D., SWARTZ, S. M. \& MARSH, R. L. (2019). Warm bodies, cool wings: regional heterothermy in flying bats. Biol Lett-UK, 15(9): 20190530. https://doi.org/10.1098/ rsbl.2019.0530

RYDELL, J., FENTON, M. B., SEAMARK, E., WEBALA, P. W. \& MICHAELSEN, T. C. (2020). White and clear wings in bats (Chiroptera). Can J Zool, 98(2): 149-156. https://doi. org/10.1139/cjz-2019-0182

SIMMONS, N. B. (2005). Order Chiroptera. In: Mammal species of the World: a taxonomic and geographic reference, Third Edition. ed.: Johns Hopkins University Press. Baltimore, USA, p.312-529.

SPEAKMAN, J. R. \& HAYS, G. C. (1992). Albedo and transmittance of short-wave radiation for bat wings. J Therm Biol, 17(6): 317-321. https://doi. org/10.1016/0306-4565(92)90040-M
SPEAKMAN, J. R., HAYS, G. C. \& WEBB, P. I. (1994). Is Hyperthermia a Constraint on the Diurnal Activity of Bats?. J Theor Biol, 171(3): 325-339. https://doi. org/10.1006/jtbi.1994.1235

UIEDA, W. (2000). A review of complete albinism in bats with five new cases from Brazil. Acta Chiropterol, 2(1): 97-105.

VAUGHAN, T. A. (1970). The transparent dactylopatagium minus in Phyllostomatid bats. J Mammal, 51(1): 142-145. https://doi.org/10.2307/1378540

VAUGHAN, T. A. \& VAUGHAN, R. P. (1986). Seasonality and the behavior of the African Yellow-Winged Bat. J Mammal, 67(1): 91-102. https://doi.org/10.2307/1381005

WICKHAM, H., CHANG, W., HENRY, L., TAKAHASHI, K., WILKE, C., WOO, K., YUTANI, H. \& UNNINGTON, D. (2016). Package 'ggplot2'. Create elegant data visualisations using the grammar of graphics. R package version 2.2.1. Stata Software Package: College Station. Texas, USA. 